\title{
MENINGKATKAN KETERAMPILAN MEMBACA AL-QUR'AN MELALUI METODE TALAQQI PADA AYAT 190-191 DAN 159 Q.S. ALI IMRAN.
}

\author{
Farikhah \\ farikhahazza@gmail.com \\ SMK Negeri 1 Balikpapan
}

\begin{abstract}
As Muslims we have an obligation to pay attention to the Qur'an, namely by always reading it, memorizing it or interpreting it. Allah (SWT) has promised the preservationists of His book in the form of reward, raised and given happiness both in the world and in the Hereafter. The problem that I found when teaching online (online) on the material aspects of the Qur'an, it turns out that many students who collect the bill of reading QS assignments. Ali Imran verses 190191 and 159 many reading errors. Therefore, it can be found that the methods used previously do not improve the ability to read the Qur'an in accordance with the rules of the law of reading or tajwid. Then it is necessary to apply some alternative solutions that are needed, namely: the right method that can improve the skills of reading the Qur'an according to tajwid rules and media that can facilitate improving the skills of reading the Qur'an according to tajwid rules. The talaqqi method makes it easier for researchers to choose the right way to convey knowledge, because of the direct interaction between teachers and students, making it easier for teachers to recognize students' personalities and abilities by using zoomeeting applications. In this study the method used is Class Action Research. The essence of the nature carried out in classroom action research (PTK) is in the framework of teachers willing to introspect, reflect, reflect or evaluate themselves so that their abilities as a teacher / teacher are expected to be quite professional. Based on the results of research it can be concluded that through the talaqqi method can improve the ability to read the Qur'an of students. This can be seen in each cycle, in the pre-cycle the average results of students' Qur'anic reading ability by $65 \%$ with incomplete categories, and only 8 students out of 23 students only reached the average grade (completed). After the first cycle, the ability to read the Qur'an rose to $85 \%$ which was categorized as complete which amounted to 17 students out of 20 students. In cycle II the ability to read the Qur'an students experienced a significant increase with an average score of 80.5 with a complete category, with the number of students completed as many as 20 students.
\end{abstract}

Keywords: the skill of reading the Qur'an. Talaqqi method

Abstrak: Sebagai umat Islam kita memiliki kewajiban dengan menaruh perhatian terhadap Al-
Qur'an yaitu dengan cara senantiasa membacanya, menghafalkannya maupun menafsirkannya.
Allah SWT telah menjanjikan bagi para pelestari kitab-Nya yaitu berupa pahala, dinaikkan
derajatnya dan diberikan kebahagiaan baik di dunia maupun di akhirat. Masalah yang saya temukan
ketika mengajar daring (online) pada materi aspek Al-Qur'an, ternyata banyak siswa yang
mengumpulkan tagihan tugas membaca QS. Ali Imran ayat $190-191$ dan 159 banyak terjadii
kesalahan bacaan. Oleh sebab itu bisa didapati metode yang digunakan sebelumnya kurang
meningkatkan kemampuan membaca Al-Qur'an sesuai kaidah hukum bacaan atau tajwid. Maka
perlu menerapkan beberapa alternatif solusi yang diperlukan yaitu: metode yang tepat yang dapat
meningkatkan keterampilan membaca Al-Qur'an sesuai kaidah tajwid dan media yang dapat
memudahkan meningkatkan keterampilan membaca Al-Qur'an sesuai kaidah tajwid. Metode
talaqqi memudahkan peneliti memilih cara yang tepat dalam menyampaikan ilmu, karena adanya
interaksi langsung antara guru dan siswa, membuat guru lebih mudah dalam mengenali kepribadian
dan kemampuan siswa dengan menggunakanaplikasi zoomeeting. Dalam penelitian ini metode
yang digunakan adalah Penelitian Tindakan Kelas. Hakikat yang dilakukan dalam penelitian 
tindakan kelas (PTK) adalah dalam rangka guru bersedia mengintropeksi, bercermin, merefleksi atau mengevaluasi dirinya sendiri sehingga kemampuannya sebagai seorang guru/pengajar diharapkan cukup professional. Berdasarkan hasil penelitian dapat disimpulkan bahwa melalui metode talaqqi dapat meningkatkan kemampuan membaca Al-Qur'an siswa. Hal tersebut dapat dilihat pada setiap siklus, pada pra siklus hasil rata-rata kemampuan membaca Al-Qur'an siswa sebesar 65\% dengan kategori tidak tuntas, dan hanya 8 siswa dari 23 siswa saja yang mencapai nilai rata-rata (tuntas). Setelah dilakukan siklus I, kemampuan membaca Al-Qur'an siswa naik menjadi 85\% yang dikategorikan tuntas yang berjumlah 17 siswa dari jumlah 20 siswa. Pada siklus II kemampuan membaca Al-Qur'an siswa mengalami peningkatan yang signifikan dengan rata-rata nilai 80,5 dengan kategori tuntas, dengan jumlah siswa yang tuntas sebanyak 20 siswa

Kata Kunci: keterampilan membaca Al-Qur'an. Metode talaqqi.

\section{Pendahuluan}

Pendidikan merupakan suatu proses untuk mengembangkan semua aspek kepribadian manusia, yang mencakup pengetahuan, nilai, sikap dan keterampilannya. Tidak hanya itu, pendidikan di masa sekarang ini sudah menjadi proses yang didalamnya memiliki maksud yaitu untuk meningkatkan kompetensi kemampuan manusia yang berkualitas baik dalam ilmu duniawi maupun ukhrowi. ${ }^{1}$

Pendidikan Agama Islam adalah mata pelajaran yang penting diajarkan di sekolah umum maupun di sekolah Islam, untuk mengajarkan Islam kepada generasi umat Islam maka diperlukan proses pendidikan. Pendidikan Islam adalah upaya manusia untuk melahirkan generasi yang baik dan unggul, generasi yang selalu menjalankan perintah Allah SWT dan menjauhi larangan Allah SWT. Al-Qur'an adalah kitab suci penyempurna dari kitab-kitab yang diturunkan sebelumnya. Al-Qur'an sebagai petunjuk kehidupan umat manusia dan sebagai obat dari segala penyakit kehidupan sosial di masyarakat. Al-Qur'an diperuntukkan bagi umat Islam yang telah dipilih oleh Allah sebagai umat terbaik dari umat lainnya. Al-Qur'an adalah mukjizat Nabi Muhammad SAW yang sangat berharga bagi umat Islam yang dahulu, sekarang hingga nanti di yaumul kiamah. Al-Qur'an merupakan firman Allah yang diturunkan kepada Nabi Muhammad SAW melalui perantara malaikat jibril dan dijadikan pedoman hidup bagi seluruh umat manusia yang beriman ${ }^{2}$

Sebagai umat Islam kita memiliki kewajiban dengan menaruh perhatian terhadap Al-Qur'an yaitu dengan cara senantiasa membacanya, menghafalkannya maupun menafsirkannya. Allah SWT telah menjanjikan bagi para pelestari kitab-Nya yaitu berupa pahala, dinaikkan derajatnya dan diberikan kebahagiaan baik di dunia maupun di akhirat. Rasulullah SAW bersabda "Sebaikbaik kalian adalah orang yang mempelajari Al-Qur'an dan mengajarkannya kepada orang lain" (HR. Bukhari)

Sudah satu tahun lebih dunia mengalami Pandemi Covid-19 yang mengharuskan dunia pendidikan untuk melaksanakan pembelajaran daring (dalam jaringan/online), dimana guru tidak bisa bertatap muka langsung dengan peserta didik, jadi guru lebih banyak memberikan tugas dan hanya sedikit terjadi interaksi. Problem yang dihadapi peserta didikpun beragama dan bermacam-macam. Mulai dari pengembangan minat, motivasi, penciptaan lingkungan, dukungan orang tua, budaya, pembagian waktu sampai pada metode yang digunakan.

\footnotetext{
${ }^{1}$ Halimi Imam. (2018). Peningkatan Hasil Belajar Fiqih Materi Shalat Jamak, Qashar, dan Jamak Qashar dengan Strategi Pembelajaran Peer Lesson Pada Siawa Kelas VII A Semester II MTs Ma'arif 3 Grabag Kabupaten Magelang. Skripsi Fakultas Tarbiayah dan Ilmu Keguruan Istitut Agama Islam Negeri Salatiga. Hal 1

2 Izzatul Jannah \& Irfan Hidayatullah (2009), 10 bersaudara bintang Al-Qur'an : kisah nyata membesarkan anak menjadi hafiz Al Qur'an dan berprestasi, Bandung: Sygma Publishing, hal 2
} 
Dari uraian di atas dapat dipahami bahwa dalam kegiatan proses pembelajaran, salah satu yang perlu disorotin yaitu dari segi metode yang digunakan dalam pembelajaran. Demikian pula dalam proses pembelajaran Pendidikan Agama Islam aspek Al-Qur'an sangat membutuhkan metode yang tepat. Karena metodelah yang menentukan cara pembelajaran dengan hasil yang baik.

Masalah yang saya temukan ketika mengajar daring (online) pada materi aspek Al-Qur'an, ternyata banyak siswa yang mengumpulkan tagihan tugas membaca QS. Ali Imran ayat 190-191 dan 159 banyak terjadii kesalahan bacaan. Oleh sebab itu bisa didapati metode yang digunakan sebelumnya kurang meningkatkan kemampuan membaca Al-Qur'an sesuai kaidah hukum bacaan atau tajwid. Maka perlu menerapkan beberapa alternatif solusi yang diperlukan yaitu : pertama: Metode yang tepat yang dapat meningkatkan keterampilan membaca Al-Qur'an sesuai kaidah tajwid. Kedua: Media yang dapat memudahkan meningkatkan keterampilan membaca Al-Qur'an sesuai kaidah tajwid

Metode talaqqi memudahkan peneliti memilih cara yang tepat dalam menyampaikan ilmu, karena adanya interaksi langsung antara guru dan siswa, membuat guru lebih mudah dalam mengenali kepribadian dan kemampuan siswa dengan menggunakanaplikasi zoomeeting. Hal ini sudah dilakukan Rasulullah SAW seperti memilih hari-hari yang tepat dalam menyampaikan ilmu.

Berdasarkan latar belakang di atas, maka penelitian tindakan kelas tertarik mengambil judul "Meningkatkan Keterampilan Membaca Al-Qur'an Melalui Metode Talaqqi QS. Ali Imran ayat 190-191 dan 159 Mata Pelajaran Pendidikan Agama Islam dan Budi Pekerti Kelas XII TKR 1 di Sekolah Menengah Kejuruan 1 Balikpapan” dengan identifikasi masalah pada Kegiatan Pembelajaran PAI saat daring (online) guru hanya sekali mendemonstrasikan bacaan QS. Ali Imran ayat 190-191 dan 159 pada siswa kelas XII TKR 1 SMK Negeri 1 Balikpapan. Objek yang di teliti adalah peningkatan keterampilan membaca Al-Qur'an dengan metode yang digunakan adalah metode Talaqqi

\section{Kajian Teori}

\section{Keterampilan Membaca Al-Qur'an}

Keterampilan membaca Al-Qur'an terdiri dari tiga kata yaitu keterampilan, membaca dan Al-Qur'an. Ketiga kata tersebut tidak berdiri sendiri, melainkan mempunyai hubungan yang erat antara satu dengan yang lain. Ketiganya mewakili satu pengertian yang utuh yakni pengertian keterampilan membaca Al-Qur'an. Definisi keterampilan itu sendiri mempunyai arti kemampuan atau kecakapan untuk melakukan sesuatu dengan baik dan cermat dalam membaca. ${ }^{3}$

Membaca menurut bahasa merupakan perhatian untuk membaca tulisan. Perhatian untuk membaca suatu tulisan itu perlu ditanamkan sejak dini. Membaca merupakan keterampilan mendasar untuk belajar dan untuk memperoleh pengetahuan, baik berupa kesenangan atau hiburan. ${ }^{4}$ Menurut pendapat awam membaca adalah mencocokkan bunyi dengan huruf, dan AlQur'an sendiri adalah kalamullah yang merupakan mukjizat, Al-Qur'an adalah kitab suci yang diturunkan Allah SWT kepada Nabi Muhammad SAW sebagai salah satu rahmat yang tidak ada

\footnotetext{
3 Tim Penyusun Kamus Pusat Pembinaan dan Pengembangan Bahasa, Kamus Besar Indonesia, Departemen Pendidikan dan Kebudayaan, (Jakarta : Balai Pustaka, cet. 4, 1993), hlm 57.

${ }^{4}$ Ibid, hlm 57
} 
taranya bagi alam semesta. Al-Qur'an adalah kalamullah atau firman Allah yang diturunkan kepada Nabi Muhammad SAW dan dipandang sebagai ibadah bila membacanya (Supandi, 2014: 3).

Dari kejadian di atas dapat ditarik benang merah bahwasannya keterampilan membaca AlQur'an adalah suatu kecakapan atau kemampuan secara baik dan benar dalam membaca ayatayat Al-Qur'an dengan cara melafalkan secara lisan yang sesuai dengan kaidah ilmu tajwid. Keterampilan membaca Al-Qur'an adalah suatu kemampuan dalam melafalkan atau melisankan huruf hijaiyah dengan benar dan tepat, dapat membaca kalimat dari rangkaian huruf hijaiyah tersebut dengan baik dan benar sesuai dengan kaidah-kaidah yang baku atau sesuai dengan ilmu tajwidnya.

Allah SWT telah memberikan jaminan mengenai kemudahan dalam mempelajari AlQur'an, sebagaimana firman-Nya dalam surah Al-Qamar (54) ayat 17 yang artinya "Dan sesungguhnya telah Kami mudahkan Al-Qur'an untuk pelajaran, maka adakah orang yang mengambil pelajaran?". Ayat ini menegaskan bahwa Al-Qur'an itu mudah diingat bagi setiap orang yang senantiasa membacanya, dan kemudahan Al-Qur'an itu juga mencakup dalam hal menghafalkannya, memahaminya, mentadaburinya dan menguak keajaiban didalamnya.

Pentingnya membaca Al-qur'an, ternyata memberikan efek-efek tertentu yang bermanfaat bagi tubuh kita. Membaca Al-Qur'an dapat mendatangkan ketenangan jiwa, kondisi jiwa akan lebih tenang, penurunan kegelisahan, terhindar dari tekanan dan lainnya. Hal ini tentu akan sangat berpengaruh baik bagi kesehatan dan akan sangat membantu aktivitas keseharian.

\section{Metode Pembelajaran Al Qur'an Talaqqi}

Nasution menyatakan bahwa "metode berasal dari bahasa yunani, yaitu methodos. Methodos berasal dari kata "meta" dan "hodos". Meta berarti melalui, sedangkan hodos berarti jalan. Sehingga metode berarti jalan yang harus dilalui atau cara untuk melakukan sesuatu atau prosedur. ${ }^{5}$ Lebih lanjut, Djajasudarman menyatakan bahwa "metode adalah cara yang teratur dan terstruktur dengan baik untuk mencapai maksud (dalam ilmu pengetahuan dan sebagainya) cara kerja yang bersistem untuk memudahkan pelaksanaan suatu kegiatan untuk mencapai tujuan yang diharapkan.

Metode menurut Kamus Besar Bahasa Indonesia (KBBI) metode adalah cara mengajar, yang digunakan untuk melaksanakan suatu pekerjaan agar tercapai sesuatu dengan yang dikehendaki. Jadi metode bisa berarti jalan atau cara yang harus dilalui untuk mencapai tujuan tertentu. Menurut Fathurahman dan M. Sobry Sutikno, metode merupakan suatu cara yang digunakan untuk mencapai tujuan yang ditetapkan (Fathurahman, 2009:15). Metode secara harfiah berarti "cara" dalam pemakaian yang umum, metode diartikan sebagai suatu cara atau prosedur yang dipakai untuk mencapai tujuan tertentu.

Salah satu keterampilan guru yang memegang peran penting dalam proses pembelajaran adalah keterampilan memilih metode. Pemilihan metode berkaitan langsung dengan usahausaha guru dalam menampilkan pembelajaran diperoleh secara optimal. Oleh karena itu, salah satu hal yang sangat mendasar untuk dipahami guru adalah bagaimana memahami kedudukan metode sebagai salah satu komponen bagi keberhasilan lain dalam keseluruhan komponen

5 Jamal Ma'mur Asmani, 7 Tips Aplikasi PAKEM (Pembelajaran Aktif, Kreatif, Efektif dan Menyenangkan), (Jogjakarta: Diva Press, 2011) hal.19 
pendidikan. Menurut Drs. H. Abu Ahmadi dan Drs. Joko Tri Prasetya, metode mengajar adalah pengetahuan tentang bagaimana cara mengajar yang dipergunakan oleh guru atau instruktur.

Menurut Muhammad, J (2011) Talaqqi adalah "belajar ilmu agama secara langsung kepada guru yang mempunyai kompetensi ilmu, tsiqah, dhabit dan mempunyai sanad keilmuan yang muttashil sampai ke Rasulullah SAW melalui para ulama aalimin aarifin".

Menurut Imana, Y. (2009, hlm.7) cara guru menyampaikan bacaan Al-Qur'an secara musyafahah (anak melihat gerak bibir guru secara tepat) yaitu berhadapan langsung dengan murid dalam posisi duduk dengan tenang dan nyaman, kemudian guru membimbing anak untuk mengulang-ulang ayat yang dibacakan dan diperdengarkan kepada anak sampai anak benarbenar hafal, maka cara yang demikian itu dikenal dengan istilah talaqqi.

Metode talaqqi dalam pembelajaran Al-Qur'an menuntut guru agar sering memberikan contoh bacaan yang benar dan fasih dalam membacakan ayat-ayat Al-Qur'an, sehingga terkadang tidak cukup hanya mencontohkan satu kali dalam pembacaan ayat-ayat Al-Qur'an, bahkan harus dilakukan secara berulang-ulang kali sampai siswa benar-benar mampu menirukan apa yang dibaca oleh guru. Hal ini membutuhkan waktu yang tidak sedikit, bahkan proses setoran bacaan atau tilawah siswa dengan cara talaqqi juga tidak bisa dilaksanakan secara maksimal, karena berbenturan dengan waktu istirahat atau jadwal pelajaran berikutnya (Hanapi, 2014).

Keunggulan metode talaqqi antara lain: 1). Menumbuhkan kedekatan antara guru dengan siswa sehingga secara emosional akan menciptakan hubungan yang harmonis. 2). Guru membimbing siswa secara berkesinambungan sehingga guru memahami karakteristik masingmasing siswa. 3). Guru dapat langsung mengoreksi bacaan siswa agar tidak keliru dalam membunyikan huruf. 4). Siswa dapat melihat langsung gerakan bibir guru dalam mengucapkan makharijul huruf karena berhadapan secara langsung.

Adapun kelemahan metode talaqqi sebagai berikut: 1). Metode talaqqi tidak bisa digunakan secara klasikal pada kelas yang jumlah siswanya banyak, karena dirasa kurang efektif dan membutuhkan waktu yang lama. 2). Guru akan menguji bacaan masing-masing siswa secara sendiri-sendiri sehingga anak yang belum mendapatkan giliran akan merasa bosan menunggu.

Dalam membaca Al-Qur'an terdapat tingkatan dalam membacanya, antara lain: 1).Tahqiq, adalah tingkatan bagi pemula yang baru belajar ilmu tajwid. Cara membacanya seperti tartil namun lebih lambat dan tenang. At-tahqiq merupakan tahapan awal sebelum masuk ke tahapan berikutnya. 2). Tartil, berarti membaca sesuai hukum tajwid. Membaca dengan tartil akan membantu untuk memahami dan mentadabburi Al-Qur'an. Tartil diartikan membaca dengan jelas makhrajnya dan ditunaikannya setiap hak, sifat huruf beserta harakatnya. 3). Tadwir, adalah tingkatan pertengahan antara perlahan dan cepat. Sering kita dengar di dalam shalat berjamaah. 4). Hadar, adalah bacaan cepat namun masih menjaga hukum-hukum tajwid. Ini merupakan tingkatan bacaan paling cepat dan sering digunakan para penghafal Al-Qur'an yang ketika mengulang hafalannya dengan cepat tetapi tetap mengindahkan hukum-hukum tajwid. ${ }^{6}$

Dalam pembelajaran Al qur'an tenetu terdapat hambatan dalam membaca Al-Qur'an. Adapun hambatan-hambatan secara umum dalam membaca Al-qur'an. Antara lain; 1). Kesulitan konsentrasi, membuat pikiran melayang entah ke mana dan huruf-huruf yang dibacapun ikut

\footnotetext{
${ }^{6}$ Artikel diakses dari https://kalam.sindonews.com ( 4 Tingkatan Membaca Al-Qur'an, Kamu yang Mana? (sindonews.com)
} 
menguap terbang. ${ }^{7}$ 2). Rendahnya motivasi dalam membaca Al-Qur'an 3). Banyak berbuat dosa dan maksiat, hal ini bisa membuat manusia lupa pada Al-Qur'an, membutakan hatinya dari ingat kepada Allah SWT dan lupa untuk senantiasa membaca Al-Qur'an setiap hari.

Pemahaman tentang Pendidikan Agama Islam (PAI) di sekolah dapat dilihat dari dua sudut pandang, yaitu PAI sebagai aktivitas dan PAI sebagai fenomena. Pada domain yang pertama dimaksudkan bahwa PAI sebagai upaya yang dilakukan secara sadar dirancang untuk membantu seseorang atau sekelompok orang dalam mengembangkan pandangan hidup dan kehidupannya, sikap hidup dan keterampilan hidup, baik yang bersifat manual (petunjuk praktis) maupun mental dan sosial yang bernafaskan atau dijiwai oleh ajaran dan nilai-nilai Islam (Hanafi, 2014). Sedangkan pemahaman PAI sebagai fenomena merupakan peristiwa perjumpaan antara dua orang atau lebih dan/atau penciptaan suasana yang dampaknya kepada berkembangnya suatu pandangan hidup yang bernafaskan atau dijiwai oleh ajaran-ajaran Islam, yang diwujudkan dalam sikap hidup serta keterampilan hidup pada salah satu atau beberapa pihak (Hanafi, 2014).

Diketahui bahwa agama Islam dan pendidikan adalah dua hal yang satu sama lain saling berhubungan. Melalui agama, manusia diarahkan menjadi manusia seutuhnya sesuai dengan nilai-nilai ajaran Islam. Proses pengembangannya adalah melalui pendidikan (Saepullah, 2012). Karena dengan pendidikan orang akan menjadi lebih dewasa dan lebih baik dari segi kecerdasannya maupun sikap mentalnya. Agama dimaksudkan untuk membentuk manusia Indonesia seutuhnya, dengan pertama-tama mengerahkan peserta didik menjadi manusia Indonesia yang beriman dan bertaqwa kepada Tuhan Yang Maha Esa (Rahardjo, 2002).

Menurut Muhaimin (2016) menyoroti kegiatan Pendidikan Agama Islam yang selama ini dilaksanakan di sekolah lebih terkonsentrasi pada persoalan teoritis dan kurang memperhatikan persoalan bagaimana mengubah pengetahuan agama yang bersifat kognitif menjadi "makna" dan "nilai" yang perlu diinternalisasikan dalam diri peserta didik, untuk selanjutnya menjadi sumber minat bagi peserta didik untuk bergerak, berbuat dan berperilaku secara kongkretagamis dalam kehidupan sehari-hari. Adapun yang penulis maksud dengan keterampilan membaca Al-Qur'an adalah keterampilan membaca Al-Qur'an yang meliputi : 1). Makharijul Huruf, yaitu sesuai dengan tempat keluarnya huruf yang berkaitan dengan pengucapan hurufhuruf Al-Qur'an secara jelas dan benar. 2). Ketepatan Tajwid, yaitu ilmu pengetahuan tentang cara membaca Al-Qur'an dengan baik sesuai dengan makharijul huruf, panjang pendeknya, tebaal tipisnya, berdengung atau tidaknya, irama dan nadanya secara benar dan tartil

\section{Metode}

Hakikat yang dilakukan dalam penelitian tindakan kelas (PTK) adalah dalam rangka guru bersedia mengintropeksi, bercermin, merefleksi atau mengevaluasi dirinya sendiri sehingga kemampuannya sebagai seorang guru/pengajar diharapkan cukup professional untuk selanjutnya diharapkan dari peningkatan kemampuan diri tersebut dapat berpengaruh terhadap peningkatan kualitas anak didiknya, baik dalam aspek penalaran, keterampilan, pengetahuan hubungan sosial maupun aspek-aspek lain yang bermanfaat bagi anak didik untuk menjadi dewasa.

Penelitian ini merupakan penelitian tindakan kelas. Dalam penelitian ini mempunyai empat kegiatan utama yang ada pada setiap siklus yaitu: Perencanaan, Tindakan, Pengamatan dan

Artikel diakses dari https://www.muhammadnoer.com/hambatan-dalam... (www.muhammadnoer.com) 
Refleksi. Penelitian yang akan dilakukan, direncanakan dalam beberapa siklus, yaitu: (a) Pra siklus, (b) siklus I dan (c) siklus II. Pada Pra siklus peneliti mencari masalah yang terjadi saat pembelajaran yang dilakukan guru yaitu guru menguji bacaan QS. Ali Imran ayat 190-191 dan 159. Dan peneliti baru menggunakan pembelajaran metode talaqqi pada siklus I yang kemudian akan melihat hasil pembelajaran metode talaqqi pada siklus ke II. Bila pada siklus I hasil dari proses pembelajaran nilainya masih dibawah $\operatorname{KKM~(75)~dan~siswa~masih~pasif~dalam~mengikuti~}$ pembelajaran, maka alternatif yang ditawarkan adalah melanjutkan sampai mendapatkan nilai sesuai KKM (75) dan aktivitas siswa meningkat dan siswa semakin bersemangat dalam mengikuti pembelajaran.

Adalah objek penelitian yang diamati sebagai variabel yaitu:

1. Kemampuan Tajwid : kemampuan tajwid yang penulis maksud untuk menjadi objek pengamatan terdiri dari dua indikator yaitu kemampuan membaca sesuai dengan hukum bacaan nun sukun atau tanwin, tentang hukum ikhfa, idzhar, idgham. Ada banyak bab pembahasan hukum tajwid, namun berdasar pengamatan pada pertemuan pra siklus ditemukan siswa yang masih belum bisa membedakan hukum bacaan secara konsisten

2. Kemampuan Makhraj : Meningkatkan keterampilan membaca Al-Qur'an dengan indikator makharijul huruf, bermuara pada kemampuan siswa membedakan huruf ha (tipis) dan ha (tebal) dan membedakan bunyi huruf sin dan syin. Makhraj yang lain sebenarnya terlihat masih perlu diperbaiki, namun untuk tahap perbaikan dua siklus pada PTK ini memprioritaskan perbaikan pada dua huruf hijaiyah tersebut, terlebih kedua huruf itu sering muncul pada QS. Ali Imran ayat 190-191 dan 159.

Populasi adalah kelompok besar individu yang mempunyai karakter umum yang sama. Dalam penelitian ini, populasi yang ada di SMKN 1 total jumlah siswa keseluruhan 2461 terdiri dari 72 kelas.

Adapun sampel dalam penelitian ini adalah siswa kelas XII TKR 1 di SMK Negeri 1 Balikpapan yang berjumlah 36 siswa yang dijadikan subjek penelitian.

Teknik pengumpulan data dalam penelitian ini dengan tes lisan saat pelaksanaan pembelajaran berlangsung dengan menggunakan metode talaqqi. Di akhir setiap siklus dilaksanakan penugasan pengumpulan video rekaman bacaan QS. Ali Imran ayat 190-191 dan 159 yang bertujuan untuk mengetahui peningkatan keterampilan membaca surah Ali Imran ayat 190-191 dan 159 setelah dilaksanakannya membaca Al-Qur'an dengan metode talaqqi. Dan dalam pemnelitian ini terdapat beberapa teknik Analisis Data yang dilakukan, antara lain: Analisis pendahuluan, langkah awal penulis akan mencari data jumlah siswa kelas XII TKR 1 yang menjadi subjek penelitian. Kemudian Analisis data dengan cara memberikan evaluasi berupa pengumpulan tugas lisan hafalan QS. Ali Imran ayat 190-191 dan 159. Hafalan direkam dalam bentuk video dan dikirimkan di LMS googleclassroom. Video yang dikumpul akan peneliti analisis menggunakan rubrik yamg berisi penilaian: Fasokha, kelancaran, makharijul huruf, tajwid fdan tertib yang kemudian diberikan nilai akhir keterampilan .

\section{Hasil dan Pembahasan}

Penelitian ini dilakukan di SMK Negeri 1 Balikpapan yang merupakan salah satu sekolah kejuruan negeri terbaik yang ada di kota Balikpapan. Sekolah yang berada di bawah naungan Dinas Pendidikan Provinsi Kalimantan Timur ini beralamat di Jl. Marsma R. Iswahyudi Sepinggan Balikpapan Selatan dengan jumlah 7 Guru Pendidikan Agama Islam yang berstatus sebagai Pegawai Negeri Sipil (PNS), yaitu 1 laki-laki dan 2 perempuan. 
SMK Negeri 1 Balikpapan berdiri sejak tahun 1985, dengan luas lahan 4,5 Ha dengan akreditasi A. SMK Negeri 1 memiliki visi sekolah berkarakter, berbudaya lingkungan dan sekolah berstandar Internasional. SMK Negeri 1 Balikpapan yang telah melahirkan ribuan lulusan yang tersebar diberbagai kota di Indonesia. Seiring berjalannya waktu SMK Negeri 1 Balikpapan terus berbenah guna menjawab tantangan jaman dengan menghadirkan lulusan terbaik sebagai wujud sumbangsihnya terhadap pembangunan di Kota Balikpapan khususnya dan Indonesia pada umumnya.

Saat ini SMK Negeri 1 Balikpapan memiliki 132 orang guru yang profesional di bidangnya, dengan 36 orang tenaga pendidik serta memiliki jumlah siswa terbanyak di tingkat provinsi Kalimantan Timur dengan jumlah 2461 siswa, dengan jumlah rombel sebanyak 71.

Sedangkan dari sisi sarana dan prasarana SMKN 1 Balikpapan memiliki 60 Ruang Kelas, 6 ruang laboratorium, 10 ruang praktek dan berbagai ruang pendukung lainnya seperti Ruang Kepala Sekolah, perpustakaan, ruang guru, ruang tata usaha, Masjid, ruang UKS dan Ruang OSIS. Dengan berbagai fasilitas yang dimilikinya, sangatlah wajar jika SMK Negeri 1 Balikpapan menjadi salah satu sekolah idaman bagi banyak orang khusunya di kota Balikpapan. Hal ini dapat terlihat dari jumlah peserta didik yang saat ini sedang menimbah ilmu di sekolah ini. Terdapat 2.461 orang peserta didik dengan 616 adalah perempuan dan 1.845 peserta didik adalah laki-laki.

Kegiatan belajar mengajar (KBM) di SMK Negeri 1 Balikpapan menerapkan 5 hari belajar dalam satu pekan. Mata pelajaran yang diajarkan meliputi adaktif, normatif dan teori kejuruan. Mata pelajaran Pendidikan Agama Islam dan Budi Pekerti masuk di pelajaran normatif yang jam mengajarnya 3 jam pelajaran setiap pekannya. Di SMK Negeri 1 Balikpapan dalam kegiatan mengajarnya menggunakan dua model yaitu sinkron dan unsinkron. Model unsinkron menggunakan LMS Googleclassroom dan whatshapp, sedangkan model sinkron yaitu Video conference bisa menggunakan zoommeeting ataupun googlemeet.

Adapun kelas yang digunakan peneliti untuk penelitian tindakan kelas yaitu kelas XII TKR 1 dan mendapatkan jadwal mata pelajaran Pendidikan agama Islam dan Budi pekerti pada hari senin di jam pertama selama 60 menit atau 1 jam (08.00-09.00 WITA). Jadwal Video conference kelas XII TKR1 saat KBM mata pelajaran Pendidikan Agama Islam pada tanggal 20 Juli 2020, yang digunakan peneliti dalam pra siklus. Siklus pertama dilaksanakan pada tanggal 27 Juli 2020 dan siklus kedua dilaksanakan pada tanggal 03 Agustus 2020. Adapun KI_KD yang digunakan sesuai permendikbud no. 37 tahun 2018, untuk buku pegangan guru dan siswa menggunakan buku terbitan kementerian Agama tahun 2019 (Buku kelas XII revisi).

\section{Kondisi Awal (Prasiklus)}

Kondisi awal atau pra siklus yang peneliti maksud yaitu kondisi dimana untuk pertamakalinya mengetahuan kemampuan membaca al-qur'an siswa pada ranah keterampilan.

Pra siklus dilaksanakan oleh peneliti pada hari senin tanggal 20 Juli 2020 dengan Video conference pada materi aspek al-Qur'an yaitu QS. Ali Imran ayat 190-191 dan 159. Hasil penelitian pada pra siklus aktivitas pembelajaran masih menggunakan metode tradisional, sehingga hasil yang dicapai masih rendah. Hal ini dibuktikan dengan hasil tes 
lisan kemampuan membaca Al-Qur'an yang diikuti 23 siswa. Oleh sebab itu perlu untuk mengambil pendekatan suatu tindakan. Berdasarkan hasil prasiklus diatas terdapat 8 siswa yang mencapai ketuntasan dengan presentase 35\%, sedangkan siswa yang belum tuntas sebanyak 15 siswa dengan presentase 65\% dengan nilai rata-rata 73, adapun KKM nya 75. Di pra siklus ini peneliti menggunakan metode tradisional berupa ceramah dan hanya sekali memberi contoh bacaan QS. Ali Imran ayat 190-191 dan 159 serta kurangnya dalam membaca kitab suci Al-Qur'an setiap hari.

\section{Siklus I}

Penelitian pada siklus ini dilaksanakan pada tanggal 27 Juli 2020. Adapun sistematis pendekatan pembelajaran dengan menggunakan metode talaqqi untuk memperbaiki kemampuan membaca Al-Qur'an terutama QS. Ali Imran ayat 190-191 dan 159 yang dilaksanakan di SMK Negeri 1 Balikpapan sebagai berikut: 1). Perencanaan, meliputi penetapan materi pembelajaran pendidikan Aspek Al-qur'an dan penetapan alokasi waktu pelaksanaannya. 2). Pelaksanaan (tindakan) meliputi seluruh proses kegiatan belajar mengajar menggunakan metode talaqqi. Adapun langkah-langkah tahap pelaksanaanya sebagai berikut:

a. Pendahuluan (10 menit)

1) Guru memberi salam pembuka dan berdo'a bersama-sama untuk memulai pembelajaran

2) Guru memeriksa kehadiran peserta didik

3) Guru menyiapkan fisik dan psikis peserta didik dalam mengawali kegiatan pembelajaran dengan Ice Breaking

4) Guru memberikan gambaran manfaat mempelajari pelajaran yang akan dipelajari dan akan diterapkan dalam kehidupan sehari-hari.

5) tujuan pembelajaran, $\mathrm{KI}, \mathrm{KD}$, Indikator pada pertemuan yang berlangsung saat ini

b. Inti ( 45 menit)

1) Mengaitkan kegiatan pembelajaran yang akan dilakukan dengan pengalaman peserta didik dan Mengajukan pertanyaan yang ada keterkaitannya dengan pelajaran yang akan dilakukan

2) Guru menjelaskan hukum bacaan

3) Guru mentalaqqi siswa bacaan QS. Ali Imran ayat 190-191 dan 159

4) Guru meminta siswa untuk membaca QS. Ali Imran ayat 190-91 dan 159

5) Guru meminta siswa untuk membaca sumber belajar lainnya secara mandiri terkait hukum bacaan/tajwid

6) Guru membagi siswa dalam 3 kelompok

7) Guru membagikan LKPD

8) Guru membagikan tugas mengidentifikasi hukum bacaan yang terdapat dalam QS Ali Imran ayat 190-191 dan 159

9) Guru meminta siswa untuk berdiskusi mengidentifikasi hukum bacaan

10) Saat siswa mengerjakan tugas secara berkelompok, guru memantau kelompok siswa yang memerlukan bantuan penjelasan

11) Guru memberikan bantuan (scaffolding) dengan memberikan clue (bukan jawaban) kepada kelompok siswa yang mengalami masalah. 
12) Setelah selesai berdiskusi, guru meminta 3 kelompok untuk mempersentasikan hasil diskusinya didepan semua teman-temannya

13) Guru meminta tanggapan dari kelompok lain

14) Guru memberikan apresiasi (reward) kepada kelompok siswa yang sudah mempresentasikan hasil diskusinya

15) Guru dan siswa menyimpulkan meteri pembelajaran

c. Kegiatan Penutup (5 menit)

16)Guru memberikan penguatan atas pembelajaran yang telah berlangsung

17)Guru mengajak siswa untuk senantiasa membaca al-qur'an sesuai makharijul huruf dan kaidah tajwid setiap hari

18)Guru memberikan tugas mendemonstrasikan hafalan QS Ali Imran ayat 190-191 dan 159

d. Observasi, dilaksanakan bersamaan dengan proses pembelajaran, meliputi aktifitas siswa dalam pembelajaran dan peningkatan partisipasi siswa dalam pembelajaran

e. Refleksi, meliputi kegiatan analisis hasil pembelajaran dan menyusun rencana perbaikan pada siklus berikutnya.

Beberapa kelemahan dan kesulitan yang ditemukan pada siklus I ini adalah:

1. Dalam metode pembelajaran Pendidikan Agama Islam, pada siklus ini dilakukan selama 60 menit, sehingga belum maksimal

2. Hanya siswa yang mengikuti pembelajaran zoometing yang menjadi sample penelitian

Dari kesulitan di atas, pada tahap refleksi, berkesimpulan untuk melakukan perbaikan yaitu dengan memberikan waktu pembelajaran metode talaqqi diluar jam pelajaran sekolah.

Hasil yang diperoleh sebagian besar siswa menunjukkan ketuntasan siswa lebih baik dibandingkan pada saat pra siklus, dimana pada saat pra siklus siswa yang tuntas hanya 8 siswa, sedangkan yang tidak tuntas ada 15 siswa. Pada siklus I diberikan tindakan dengan menggunakan metode talaqqi sudah terlihat dengan jumlah ketuntasan siswa sebanyak 17 siswa dan 3 siswa yang belum tuntas. Pada siklus I ini, nilai siswa dengan nilai rata-rata 77,45 .

\section{Siklus II}

Siswa diminta untuk mengirim rekaman video hafalan QS. Ali Imran ayat 190-191 dan 159 dengan fasih dan lancar sesuai makharijul huruf dan hukum bacaan.

Berdasarkan hasil yang diperoleh pada sikus II di atas, menunjukkan kegiatan siswa dalam setoran hafalan sudah membaik dan upaya untuk meningkatkan kemampuan membaca AlQur'an sudah terlaksana dengan baik dan memuaskan, bisa dilihat rata-rata nilai siswa adalah 80 dan presentase siswa yang tuntas 100\%. 


\section{A. Analisis Data}

Dari hasil 3 siklus, diperoleh data yang menghasilkan rata-rata dengan setiap siklus sebagai berikut:

Berdasarkan hasil rata-rata siklus pada tabel di atas, menunjukkan kegiatan siswa dalam setoran hafalan sudah membaik dan upaya untuk meningkatkan kemampuan membaca Al-Qur'an sudah terlaksana dengan baik dan memuaskan. Bisa dilihat rata-rata nilai siswa saat pra siklus adalah 73 , nilai terendah 60 , nilai tertinggi 80 , jumlah siswa yang tuntas hanya 8 siswa dan yang belum tuntas ada 15 siswa dari 23 siswa. Setelah dilakukan perbaikan pada siklus I, tingkat pemahaman siswa terhadap materi aspek Al-Qur'an semakin meningkat sehingga mengalami peningkatan rata-rata nilai siswa menjadi 77,45 , nilai terendah 70 , nilai tertinggi 85 , jumlah siswa yang tuntas 17 siswa dan yang belum tuntas tinggal 3 siswa dari 20 siswa. Kemudian pada siklus II meningkat dengan hasil yang sangat mengagumkan dengan rata-rata siswa 80,5 , nilai terendah 75 , nilai tertinggi 90 , dan semua siswa tuntas sebanyak 20 siswa.

Perbandingan dan peningkatan yang diperoleh pada pra siklus, siklus I dan siklus II sebagai berikut:

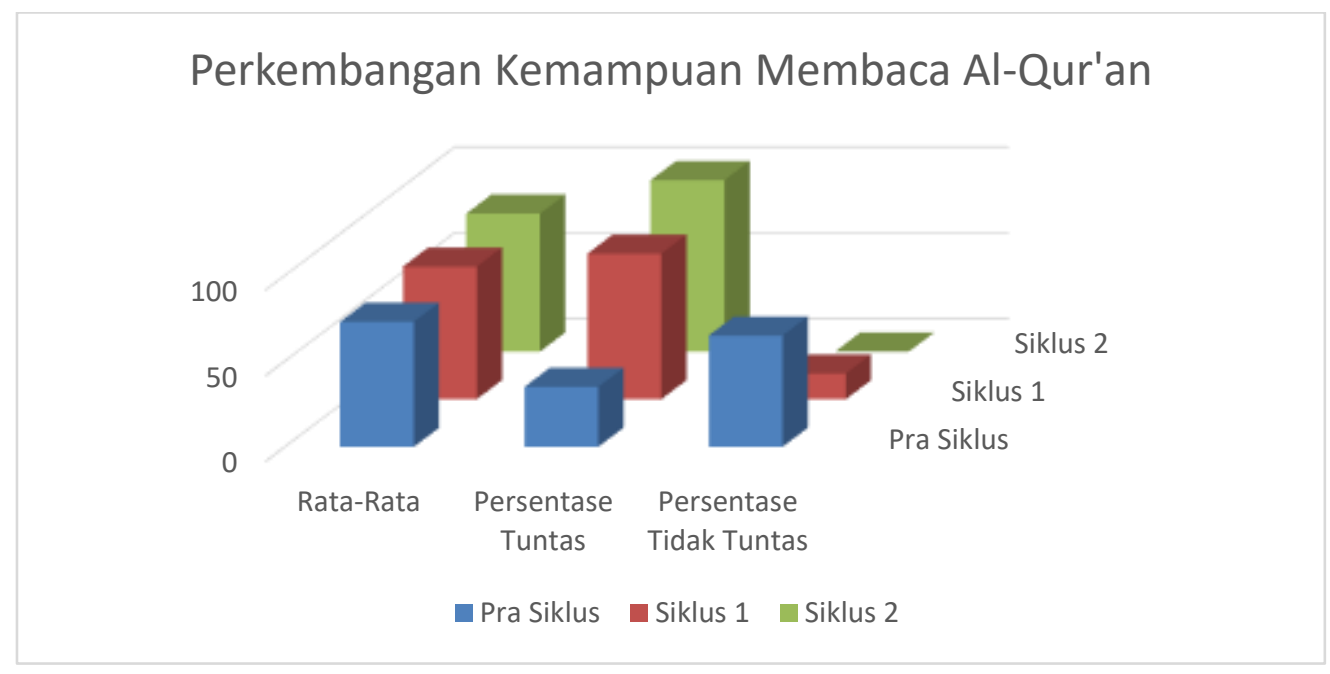

\section{Hasil Analisis Penelitian}

Indikator keberhasilan penelitian ini adalah meningkatnya kemampuan membaca $\mathrm{Al}$ Qur'an siswa kelas XII TKR 1 di SMK Negeri 1 Balikpapan. Menurut Mulyasa proses pembelajaran dikatakan berhasil apabila di dalam kelas ada 75\% siswa terlibat aktif dalam proses pembelajaran.

Berdasarkan data yang diperoleh dari hasil perbandingan dan peningkatan yang diperoleh pada pra siklus, siklus I dan siklus II menunjukkan bahwa tindakan yang dilakukan pada siklus I dengan menggunakan metode talaqqi pada aspek Al-Qur'an dapat meningkatkan kemampuan membaca Al-Qur'an materi QS. Ali Imran ayat 190-191 dan 159. Jika dibandingkan dengan hasil pra siklus, sudah mengalami pencapaian yang signifikn pada siklus ke II yang dibuktikan dari nilai rata-rata siswa yaitu 80 dan sudah mencapai Kriteria Ketuntasan Minimum (KKM). Terdapat peningkatan kegiatan membaca Al-Qur'an dari pra siklus ke siklus I dan siklus II. Hal ini menunjukkan bahwa kegiatan membaca Al-Qur'an menggunakan metode talaqqi dapat 
meningkatkan kemampuan membaca Al-Qur'an QS. Ali Imran ayat 190-191 dan 159 siswa kelas XII TKR 1 SMK Negeri 1 Balikpapan.

\section{Kesimpulan}

Berdasarkan hasil penelitian dapat disimpulkan bahwa melalui metode talaqqi dapat meningkatkan kemampuan membaca Al-Qur'an siswa. Hal tersebut dapat dilihat pada setiap siklus, pada pra siklus hasil rata-rata kemampuan membaca Al-Qur'an siswa sebesar 65\% dengan kategori tidak tuntas, dan hanya 8 siswa dari 23 siswa saja yang mencapai nilai rata-rata (tuntas). Setelah dilakukan siklus I, kemampuan membaca Al-Qur'an siswa naik menjadi 85\% yang dikategorikan tuntas yang berjumlah 17 siswa dari jumlah 20 siswa. Pada siklus II kemampuan membaca AlQur'an siswa mengalami peningkatan yang signifikan dengan rata-rata nilai 80,5 dengan kategori tuntas, dengan jumlah siswa yang tuntas sebanyak 20 siswa. Berdasarkan hasil penelitian ini, peneliti merekomendasikan kepada guru dan siswa sebagai berikut: 1). Metode talaqqi pada mata pelajaran Pendidikan Agama Islam dan Budi Pekerti Aspek Al-qur'an pada materi pembelajaran membaca Al-Qur'an dapat meningkatkan keterampilan siswa dalam membaca dan menghafal surah/ayat AlQur'an, sehingga dapat dijadikan acuan dan alternatif dalam menerapkan metode belajar membaca Al-Qur'an di kelas XII TKR 1 SMK Negeri 1 Balikpapan maupun diluar kegiatan belajar mengajar dikelas, seperti kegiatan tahfidz pada hari sabtu. 2). Diharapkan agar siswa lebih giat dan semangat dalam membaca ataupun menghafal Al-Qur'an, sehingga penerapan metode talaqqi berlangsung dengan baik, lancar dan efektif

\section{Daftar Pustaka}

Arikunto, Suharsimi. Penelitian Tindakan Kelas. Jakarta : Bumi Aksara. 2006

Arikunto, Suharsimi. Prosedur Penelitian (Suatu Pendekatan Praktik). Jakarta : PT Rineka Cipta. 2013

Asmani, Jamal Ma'mur. 7 Tips Aplikasi PAKEM (Pembelajaran Aktif, Kreatif, Efektif, dan Menyenangkan). Jogjakarta: Diva Press. 2011

Halimi Imam. (2018). Peningkatan Hasil Belajar Fiqib Materi Shalat Jamak, Qashar, dan Jamak, Qashar dengan Strategi Pembelajaran Peer Lesson Pada Siawa Kelas VII A Semester II MTs Ma'arif 3 Grabag Kabupaten Magelang. Skripsi Fakultas Tarbiayah dan Ilmu Keguruan Istitut Agama Islam Negeri Salatiga

Hamali, Oemar. Proses Belajar Mengajar. Jakarta : PT Bumi Aksara. Cet. Ke-14. 2012

Iskandar. Penelitian Tindakan Kelas. Jakarta : Gaung Persada Pres. 2012

Izzatul Jannah \& Irfan Hidayatullah (2009), 10 bersaudara bintang Al-Qur'an : kisah nyata membesarkan anak menjadi hafiz Al Qur'an dan berprestasi, Bandung: Sygma Publishing

Sugiyono. Metode Penelitian Kuantitatif, Kualitatif dan R \& D. Bandung : CV. Alfabeta. Cet. Ke-26. 2017 
Sugiyono. Metode Penelitian Pendidikan Pendekatan Kuantitatif, Kualitatif, dan R \& D. Bandung: Afabeta. 2011

Supandi. Ulumul Qur'an. Sukoharjo: Efude Press. 2014

Tim Penyusun Kamus Pusat Pembinaan dan Pengembangan Bahasa, Kamus Besar Indonesia, Departemen Pendidikan dan Kebudayaan, (Jakarta : Balai Pustaka, cet. 4, 1993) 